\title{
E-Learning Evaluation Using PIECES Framework at Mercubuana University
}

\author{
Nia Kusuma Wardhani \\ Mercubuana University \\ Jakarta, Indonesia \\ Nia.kusuma@mercubuana.ac.id
}

\author{
Windu Gata \\ STMIK Nusa Mandiri \\ Jakarta, Indonesia \\ windugata@gmail.com
}

\begin{abstract}
Mercubuana University (UMB) is a private university that was getting Higher Education Accreditation (AIPT) with an A in 2016. UMB has implemented E-learning since 2009 in all faculties. E-learning users, such as students and professors, can use an E-Learning Mercubuana University for $\mathbf{2 4}$ (twenty-four) hours with a range of facilities as well as the use of Single Sign On for login. Facilities at E-Learning are the Dashboard, Course Overview, Forum, Quiz, Assignment, and others. In this research, the questionnaire was designed using the framework of PIECES modification and distributed to 23 lectures and 23 students related to college the first semester of 2016-2017 with a sample random sampling method. The results of Implementation of online courses at the University Mercubuana agree in Performance, Information, Economic, Control, and Service. As for the assessment of the implementation Efficiency to E-Learning is Strongly Agree.
\end{abstract}

Keywords---PIECES, E-Learning, University Education, ELearning Management, Moodle.

\section{INTRODUCTION}

Education using the internet, known as E-Learning become one of the teaching and learning methods that implemented by Mercubuana University since 2009. E-Learning applied Learning Management System (LMS) Moodle web based application developed by Information Technology department. The purpose of the use of the application is to increase the quality of learning. The online application allows students to learn without limits time and place.

E-Learning method has been applied to all faculties at the Mecubuana University, namely the Faculty of Design and Creative Arts, Faculty of Engineering, Faculty of Computer Science, Faculty of Economics and Business, Faculty of Communication, Faculty of Psychology, and Masters. There are two types of the meetings of E-Learning, namely Face to Face in The Class number 4 (four) meetings, midtest 1(one) meeting, final exams number 1 (one) meeting and online method using internet facilities number 8 (eight) meetings.

Students and teachers can use Mercubuana University's ELearning for 24 hours with a range of facilities and the use of Single Sign On of user and password. Facilities in E-Learning are the Dashboard, Course Overview, Forum, Quiz, Assigment, and others.
This E-Learning need to be evaluated, so with the evaluation can make E-Learning run better. Evaluation in thise study will use the framework PIECES (Performance, Information, Economic, Control. Service) and it is used to construct the quistionare (qualitative and quantitative models) and use Likert to make measurement of the value of each question. The questionare distributed to the odd semester in 2016-2017 to lectures and students of Mercubuana University.

\section{A. E-learning}

Development of computer technology, especially the internet, is fast developing makes very possibility for education or course to use the Internet. Roosenberg (2001), cited by Khan, said: "Internet technologies have fundamentally altered the technological and economic landscapes so radically that is now possible to quantum leaps in the use of technology for learning" [1]. There are numerous names for online learning activities, including e-learning, Web-based learning (WBL), Web-based instruction (WBI), Web-based training (WBT), Internet-based Training(IBT), distributed learning (DL), Advanced distributed learning(ADL), distance learning, online learning (OL), off-site learning (m-learning), or nomadic learning, remote learning, a-learning and others". Mention of E-Learning at the Mecubuana University is Kuliah Online.

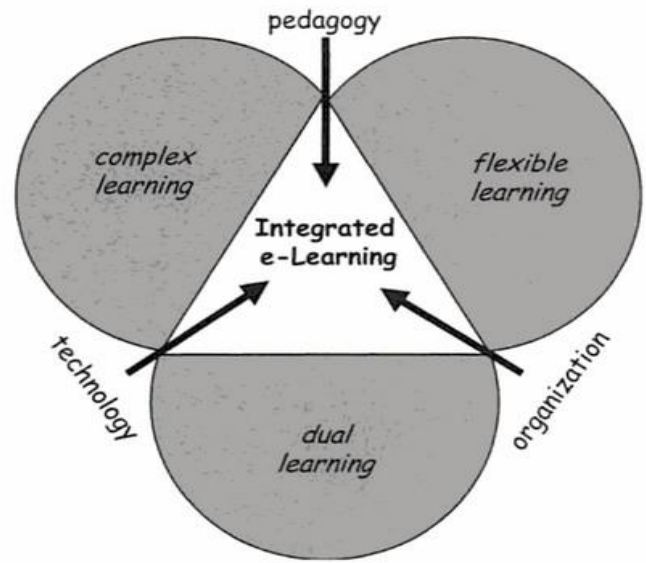

Fig. 1: Educational systems approach to integrated e-learning

Jochems refering Banathy 1996, "Integration of the different viewpoints is best guaranteed by using a systems approach for educational change. The complete educational system should be considered, at least from the viewpoints 
mentioned, if change made to it. From this point if view the introduction of e-learning is not considered merely as an addition to instruction, but as an innovation, an integral part of the educational cystem. Accordingly, a redesign of the educational system is needed in orthe to arrice at added 'learning value' for instance in terms of higher order learning outcomes. Thus organizational, pedagogical and technological aspects have to be managed in harmony in order to solve an educational problem adequately" [2].

There are differences in the role of students and teachers in teaching and learning traditional versus E-Learning according MC. Login and R. Oliver cited by Berenda following table below [3]:

TABLE I. TEACHER-STUDENT ROLES IN TRADITIONAL VERSUS ONLINE LEARNING ENVIRONMENTS

\begin{tabular}{|c|c|c|c|}
\hline Type of Role & Teacher Role & Student role & $\begin{array}{c}\text { Learning } \\
\text { Environment }\end{array}$ \\
\hline $\begin{array}{l}\text { Traditional } \\
\text { role in face- } \\
\text { to-face class }\end{array}$ & $\begin{array}{l}\text { Manager, } \\
\text { expert, } \\
\text { diciplinenarian, } \\
\text { controller, } \\
\text { dispenser of } \\
\text { information, } \\
\text { goal setter, time } \\
\text { keeper }\end{array}$ & $\begin{array}{l}\text { Listener, } \\
\text { receiver, } \\
\text { novice, } \\
\text { passive } \\
\text { learner, } \\
\text { reliant on } \\
\text { instructor for } \\
\text { assessment } \\
\text { learning }\end{array}$ & \multirow{2}{*}{$\begin{array}{l}\text { Objectivist, directed or } \\
\text { teacher centered, much } \\
\text { teacher scaffolding, use } \\
\text { suplantive strategies, } \\
\text { highly structured } \\
\text { Constructivist, leaner } \\
\text { centered, emphasis on } \\
\text { collaborative learning, } \\
\text { use of generative } \\
\text { learning strategies, less } \\
\text { or adaptive teacher } \\
\text { scaffolding, peer } \\
\text { scaffolding }\end{array}$} \\
\hline $\begin{array}{l}\text { Supportive } \\
\text { role in online } \\
\text { learning }\end{array}$ & $\begin{array}{l}\text { Resource, } \\
\text { coparticipant, } \\
\text { scaffolder, } \\
\text { colearner, } \\
\text { moderator, } \\
\text { facilitator, } \\
\text { coach, monitor, } \\
\text { advisor }\end{array}$ & $\begin{array}{l}\text { Problem } \\
\text { solver, } \\
\text { explorer, } \\
\text { researcher, } \\
\text { collaborator, } \\
\text { goal setter, } \\
\text { moderator, } \\
\text { facilitator, } \\
\text { scaffolder, } \\
\text { participant }\end{array}$ & \\
\hline
\end{tabular}

\section{B. PIECES}

Wetherbe and Vitalari proposed Framework PIECES cited by [4], "PIECES is an acronym for performance, information, economics, control, efficiency, and service and is used as checklist for identifing problems and determining priorities fro developing new information systems". For further explanation is as follows [5]:

- Performance, Performance is related to timeliness in terms of the system responding to user requests to provide current, up-to-date data. Performance also extends to a consideration of the total amount of work that can be put through the system in a given time.

- Information related to several DQ dimensions. it includes lack of necessary information, irrelevant information, too mauch information, information that is not formatted propperly, inaccurate information, information that is not timely, and information that is difficult or costly to produce. It also includes data capture, data redundancy, data inconsistency due to redudancy, and data that is not secure, not organized, not flexible and not accessible
- Economic covers cost (unknown, untraceable, too high) and profits (find new markets, improve old markets, and increase orders).

- Control involves security, either too much or too little. Inadequate security can lead to fraud, embezzlement, and potential privacy violations.

- Efficiency considers time wasting activities, especially those caused by redundancy.

- Service includes many aspects of accuracy as well as ease of use.

\section{METHODS}

This study uses PIECES Framework where the questions were designed with quantitative and qualitative methods that can be used in management education. Quantitative methods in the questioner using the measurement of Likert scale consisting of five (5) votes, ie Strongly Disagree (score 1), Disagree (score 2), Fair (score 3), Agree (score 4), and Strongly Agree (score 5). Qualitative methods are expected to get an opinion from responden regrading problem and solutions that are suggestion of respondent can be studied, so can be strategies that are interactive and flexible.

Based on the above, the design of the question in the research questioner that uses PIECES with modification, as follows:

- P(erformance). Do you think that E-Learning can improve and maintan learning process and ensure consistaency, completeness and quality?

- I(nformation). Do you think that E-Learning make excellent information information communication between university and student?

- $\mathrm{E}$ (conomic). Do you think that the use of E-Learning can save costs?

- $\mathrm{C}$ (ontrol). Whether using E-learning can improve the accuracy, interaction and feedback in the online materials as well as increase the opportunities students can ask questions directly to the lecturer and vice versa?

- E(ffeciency). Does the existence of E-Learning can increase the Efficiency to specific problems such as time, location constraints, slow response and paperless?

- S(ervice). Is the use of E-Learning outcomes is becoming easier rather than face to face in the class?

At each question there is a qualitative inquiry command which is optionally filling, are as follows: "Please give reasons why and if there are problems please give a solution!".

\section{Mercubuana University}

In December 2016, Mercubuana University established in 1985 in the region Kopertis III Indonesia in the region Kopertis III Indonesia, got the Accreditation of Higher Education (Akreditasi Institusi Perguruan Tinggi-AIPT) with score A [1].

Founder of the University Mercubuana is an entrepreneur named $\mathrm{H}$. Probosutedjo and has experience as a teacher in 
Taman Siswa Siantar, North Sumatra. Date October 22, 1985, he established the University Mercubuana with faculties and departments as follows: Faculty of Engineering, Department of Architecture and Civil Engineering Department; Faculty of Agriculture, Department of Social Economics of Agriculture (Agribusiness) and the Department of Agriculture (Agronomy); and the Faculty of Economics, Department of Management and Accounting. Currently, the development of the University Mercubuana very rapidly, and the faculty and the department becomes more, namely: the Faculty of Design and Creative Arts, Faculty of Engineering, Faculty of Computer Science, Faculty of Economics and Business, Faculty of Communication, Faculty of Psychology, and Masters.

\section{RESULT AND DISCUSSION}

Ref. [3] in his research titled "Performance in e-learning: online participation and student grades" has the following results: The findings revealed that greater online interaction did not lead to significantly higher performance for students achieving passing grades; however, students who failed in their courses tended to interact less frequently. Other factors that may be salient in online interactions are discussed.

Ref. [6] in his research titled "An Evaluation of the Effectiveness of E-Learning, Mobile Learning, and InstructorLed Training in Organizational Training and Development" that Learning effectiveness was measured by the change in score between the pre- and post-assessment. An ANOVA was performed to determine whether any difference in effectiveness was significant. Learners were also surveyed to capture demographic information. This research showed no significant difference in learning effectiveness among the Face To Face (FTF), e-learning, and mobile learning groups. Based on these findings, it was concluded that mobile learning and e-learning offer the same outcome as FTF training. Therefore, managers must consider other factors, such as cost and deployment time, when selecting a training delivery method.

Ref. [7] in their research titled "Evaluating Usability of ELearning Systems in Universities" study affect e-learning systems in Kenyan universities. The study had two-fold objectives; determining status of e-learning platforms and evaluating usability issues affecting e-learning adoption in Kenyan universities. The research took a case study of one of the public universities which has implemented Moodle elearning system. The usability attributes evaluated were userfriendliness, learnability, technological infrastructure and policy.

In this study, all components of PIECES framework are used to evaluate E-Learning and the questionnaire was designed using it and distributed to personal related to college the first semester of 2016-2017 with a sample random sampling method with a total of 223 personal, with details as follows: some 23 professors and students of some 200 people. Gender comparison of sources, namely: some 182 men and women some 41 people. The faculties participating filling questionnaire, Faculty of Economics and Business 27 people, the Faculty of Computer Science 136, Faculty of Engineering, some 59 people, and a Postgraduate number 1 person. The data were processed using descriptive statistics with Minitab application.
Any questions from the questioner use the LIKERT scoring method. Rensis Likert, a sociologist at the University of Michigan, was concerned with measuring psychological attitudes in a scientific way. Specially, he sought to create a reasonable measurement using a proper metric scale that would measure respondent's attitudes (Uebersax, 2006). In this study refers to Tullis who suggests that a typical item in a Likert scale is a statement to which respondents rate their level of agreement. The statement may be positive or negative. Usually, a five-point scale of agreement like the following is used [8]: 1). Strongly disagree, 2). Disagree, 3). Neither agree nor disagree, 4). Agree, 5). Strongly agree.

\section{A. Performance}

Assessment of Performance in E-Learning is as follows of some 223 people filling the questionnaire there are 12 people who Strongly Agree, Agree 91 people, Fair 91 people, Disagree 25 people, and Strongly Disagree 4 people. The results of data processing can be seen in Fig. 2, as follows:

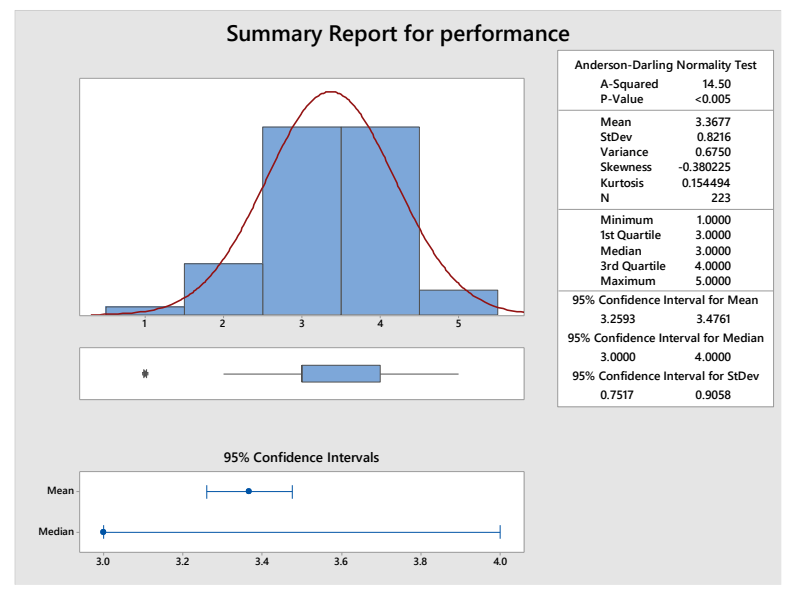

Fig. 2: Summary Report for Performance

While the results of the Likert scale in the Performance ratings have results can be seen in Table II, as follows:

TABLE II. LIKERT RESULT FOR PERFORMANCE

\begin{tabular}{|l|l|r|r|r|}
\hline$\#$ & Rate & $\begin{array}{r}\text { Total } \\
\text { Vote }\end{array}$ & Weight & Total Likert \\
\hline 1. & Strongly Agree & 12 & 5 & 60 \\
\hline 2. & Agree & 91 & 4 & 364 \\
\hline 3. & Fair & 91 & 3 & 273 \\
\hline 4. & Disagree & 25 & 2 & 50 \\
\hline 5. & Strongly Disagree & 4 & 1 & 4 \\
\hline \multicolumn{4}{|c|}{ Max Likert = 223 * 5 } & 1,115 \\
\hline \multicolumn{4}{|c|}{ Likert (in \%)= Total Liker / Max Likert *100 } & 67.35 \\
\hline \multicolumn{4}{|c|}{ Statment } & $\begin{array}{c}\text { (between 60- } \\
79.99) \text { Agree }\end{array}$ \\
\hline
\end{tabular}

The results of the assessment for Performance, respondents said Agreed that E-Learning can improve and maintain the learning processes ensure consistency, completeness and quality of the Mercubuana University's E-Learning.

While the results of respondents' opinions regarding Performance is a learning process can be done in addition to 
on-campus or erect and to students who are also the status of workers was greatly aided by the E-Learning. While the opinion of the lecturer is to some subjects that are practical and can not count on-the-Online because it resulted from Student Performance decline so that better use of teaching and learning with face to face method or class. The things that are considered to reduce the value of Performance is the frequent access to the application servers are often problematic, especially Saturday and Sunday.

\section{B. Information}

Assessment of Information in E-Learning is as follows of 223 people filling the questionnaire there are 5 people who Strongly Agree, Agree 73 people, Fair 90 people, Disagree 26 people, and Strongly Disagree 9 people. The results of data processing can be seen in Fig. 3, as follows:

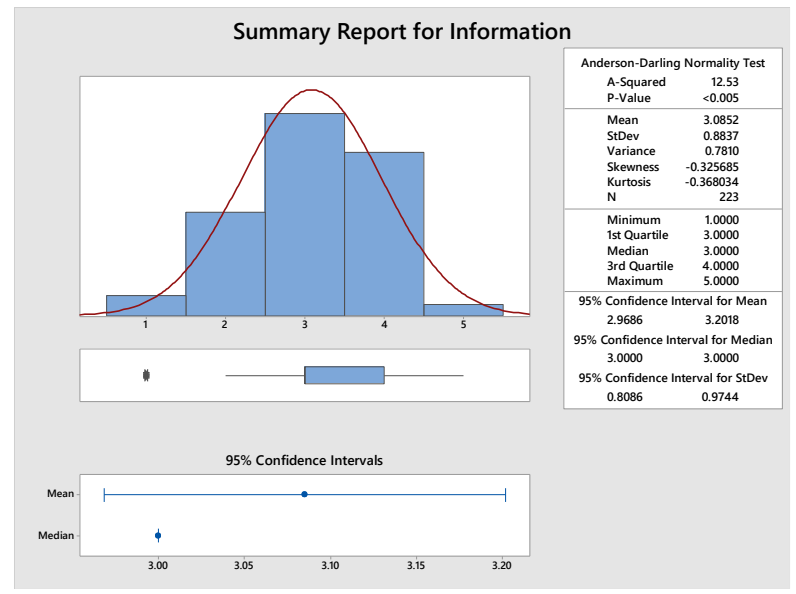

Fig. 3: Summary Report for Information

While the results of the Likert scale in the Information ratings have results can be seen in Table III, as follows:

TABLE III. LIKERT RESULT FOR INFORMATION

\begin{tabular}{|l|l|r|r|r|}
\hline$\#$ & Rate & $\begin{array}{r}\text { Total } \\
\text { Vote }\end{array}$ & Weight & Total Likert \\
\hline 1. & Strongly Agree & 5 & 5 & 25 \\
\hline 2. & Agree & 73 & 4 & 292 \\
\hline 3. & Fair & 90 & 3 & 270 \\
\hline 4. & Disagree & 26 & 2 & 92 \\
\hline 5. & Strongly Disagree & 9 & 1 & 688 \\
\hline \multicolumn{4}{|c|}{ Max Likert = 223* 5 } & 1,115 \\
\hline \multicolumn{4}{|c|}{ Likert (in \%)= Total Liker / Max Likert * 100 } & 61.70 \\
\hline \multicolumn{4}{|r}{ Statment } & $\begin{array}{c}\text { (between 60- } \\
\text { 79.99) Agree }\end{array}$ \\
\hline
\end{tabular}

The results of the assessment for Information, respondents said Agreed that E-Learning can improve and maintain the learning processes an ensure consistency, completeness, and quality of the Mercubuana University's E-Learning.

Mercubuana University's E-Learning application has a complete, but the learning process becomes ineffective when lecture and students are not active in progress, in particular on the forum. Lectures often only provide information at the beginning of the end of the last closing time. Similarly, the student work on the forum and the task at late time. Most respondents also wanted a video conference and chat module to facilitate the learning process.

\section{Economic}

Assessment of Economic in E-Learning is as follows of 223 people filling the questionnaire there are 53 people who Strongly Agree, agree 126 people, Fair 31 people, Disagree 10 people, and Strongly Disagree 3 people. The results of data processing can be seen in Fig. 4, as follows:

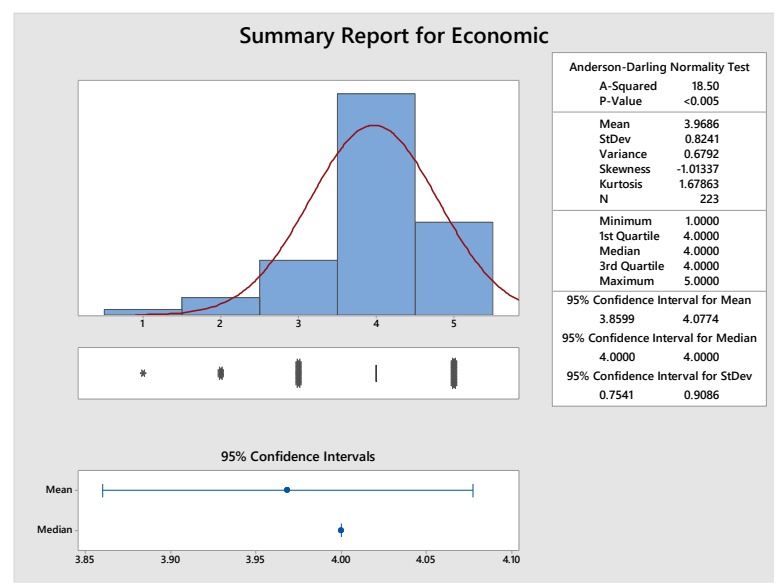

Fig. 4: Summary Report for Economic

While the results of the Likert scale in the Economic ratings have results can be seen in Table IV, as follows:

TABLE IV. LIKERT RESULT FOR INFORMATION

\begin{tabular}{|c|c|c|c|c|}
\hline$\#$ & Rate & $\begin{array}{r}\text { Total } \\
\text { Vote }\end{array}$ & Weight & Total Likert \\
\hline 1. & $\begin{array}{l}\text { Strongly } \\
\text { Agree }\end{array}$ & 53 & 5 & 265 \\
\hline 2. & Agree & 126 & 4 & 504 \\
\hline 3. & Fair & 31 & 3 & 93 \\
\hline 4. & Disagree & 10 & 2 & 20 \\
\hline 5. & $\begin{array}{l}\text { Strongly } \\
\text { Disagree }\end{array}$ & 3 & 1 & 3 \\
\hline \multicolumn{4}{|c|}{ Total Likert } & 885 \\
\hline \multicolumn{4}{|c|}{ Max Likert $=223 * 5$} & 1,115 \\
\hline \multicolumn{4}{|c|}{$\begin{array}{r}\text { Likert (in \%) = Total Liker } / \text { Max Likert } * \\
100\end{array}$} & 79.37 \\
\hline \multicolumn{4}{|r|}{ Statment } & (between 60-79.99) Agree \\
\hline
\end{tabular}

The results of the assessment for Economic, respondents said Agreed that E-Learning can improve and maintain the learning processes to ensure consistency, completeness, and quality of the Mercubuana University's E-Learning.

It can reduce the cost because there is need to come to the campus, so that not only the costs of the fare as well in the terms of dining. Since it not necessary to the campus, respondents can do the work everywhere and every time. Respondents argued that the work could be hampered if the internet quotas are insufficient. Moreover, in places or areas that have limited internet.

\section{1) Control}

Assessment of Control in E-Learning is as follows of 223 people filling the questionnaire there are 4 people who Strongly Agree, Agree 74 people, Fair 89 people, disagree 48 people, and 
Strongly Disagree 8 people. The results of data processing can be seen in Fig. 5, as follows:

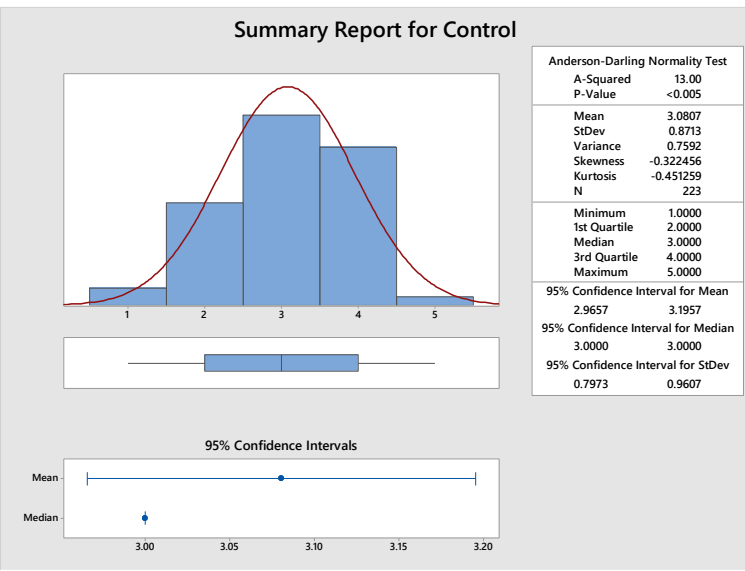

Fig. 5: Summary Report for Control

While the results of the Likert scale in the Control ratings have results can be seen in Table $\mathrm{V}$, as follows:

TABLE V. LIKERT RESULT FOR CONTROL

\begin{tabular}{|l|l|r|r|r|}
\hline$\#$ & Rate & $\begin{array}{r}\text { Total } \\
\text { Vote }\end{array}$ & Weight & Total Likert \\
\hline 1. & Strongly Agree & 4 & 5 & 20 \\
\hline 2. & Agree & 74 & 4 & 296 \\
\hline 3. & Fair & 89 & 3 & 267 \\
\hline 4. & Disagree & 48 & 2 & 96 \\
\hline 5. & Strongly Disagree & 8 & 1 & 687 \\
\hline \multicolumn{4}{|r|}{ Max Likert = 223* 5 } & 1,115 \\
\hline \multicolumn{4}{|c|}{ Likert (in \%)= Total Liker / Max Likert * 100 } & 61.61 \\
\hline \multicolumn{4}{|r}{ Statment } & $\begin{array}{c}\text { (between 60- } \\
79.99) \text { Agree }\end{array}$ \\
\hline
\end{tabular}

The results of the assessment for Control, respondents said Agreed that E-Learning can improve and maintain the learning processes an ensure consistency, completeness and quality of the Mercubuana University's E-Learning.

From the table 5, showed that the respondents agree to use E-Learning can improve, interaction, and feedback in the online materials as well as increase the opportunities to student to ask questions directly to the lecturer and vice versa. The Application is considered safe to support the learning process.

\section{2) Efficiency}

Assessment of Efficiency in E-Learning is as follows of 223 people filling the questionnaire there are 56 people who Strongly Agree, Agree 129 people, Fair 31 people, Disagree 5 people, and Strongly Disagree 2 people. The results of data processing can be seen in Fig. 6, as follows:

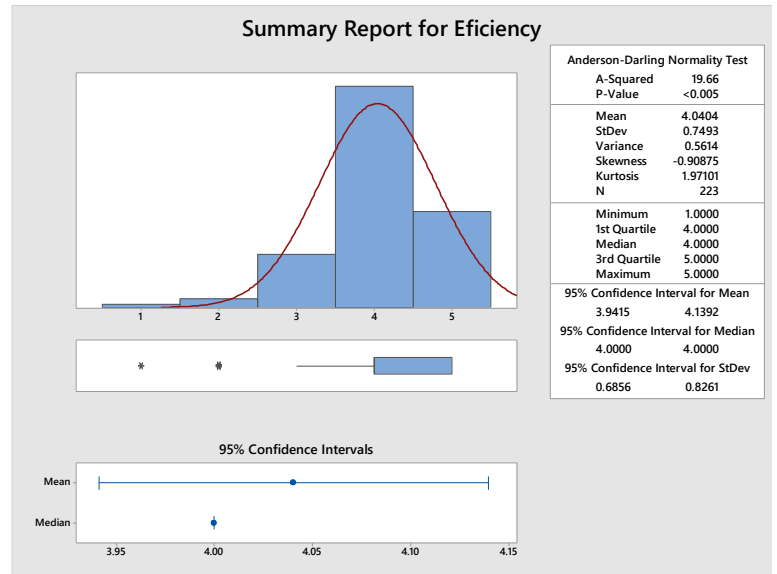

Fig. 6: Summary Report for Efficiency

While the results of the Likert scale in the Efficiency ratings have results can be seen in Table VI, as follows:

TABLE VI. LIKERT RESULT FOR EFFICIENCY

\begin{tabular}{|l|l|r|r|r|}
\hline$\#$ & Rate & $\begin{array}{r}\text { Total } \\
\text { Vote }\end{array}$ & Weight & Total Likert \\
\hline 1. & Strongly Agree & 56 & 5 & 280 \\
\hline 2. & Agree & 129 & 4 & 516 \\
\hline 3. & Fair & 31 & 3 & 93 \\
\hline 4. & Disagree & 5 & 2 & 10 \\
\hline 5. & Strongly Disagree & 2 & 1 & 2 \\
\hline \multicolumn{4}{|c|}{ Max Likert = 223 * 5 } & 901 \\
\hline \multicolumn{4}{|c|}{ Likert (in \%)= Total Liker / Max Likert * 100 } & 80.81 \\
\hline \multicolumn{4}{|c|}{ Statment } & $\begin{array}{c}\text { (between 80-100) } \\
\text { Strongly Agree }\end{array}$ \\
\hline
\end{tabular}

Based on table 6, the results of Likert that respondents Strongly Agree with the E-Learning can increase the efficiency of the organization to a specific problem such as time, location constraints, slow response and the use of paper.

\section{3) Service}

Service assessment in E-Learning is as follows of 223 people filling the questionnaire there are 9 people who Strongly Agree, Agree 74 people, Fair 79 people, Disagree 52 people, and Strongly Disagree 9 people. The results of data processing can be seen in Fig. 7, as follows:

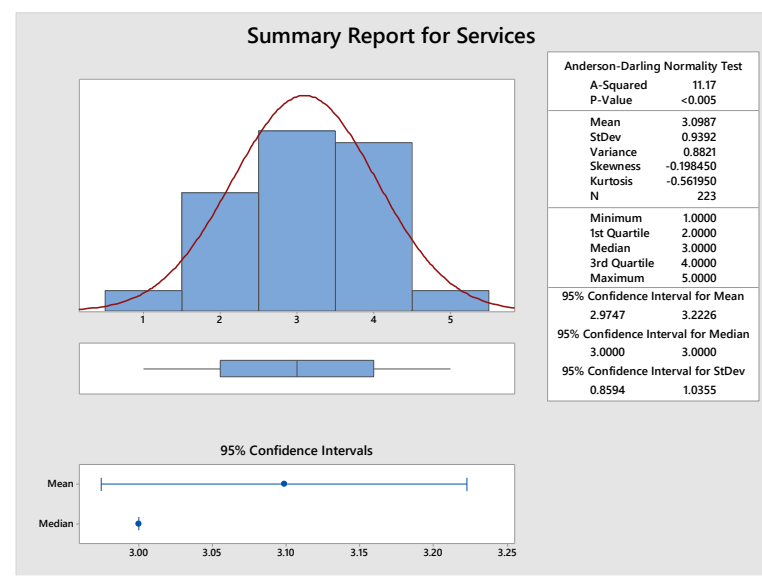

Fig. 7: Summary Report for Service 
While the results of the Likert scale in the Service ratings have results can be seen in Table VII, as follows:

TABLE VII. LIKERT RESULT FOR SERVICE

\begin{tabular}{|c|c|c|c|c|}
\hline$\#$ & Rate & $\begin{array}{c}\text { Total } \\
\text { Vote }\end{array}$ & Weight & Total Likert \\
\hline 1. & Strongly Agree & 9 & 5 & 45 \\
\hline 2. & Agree & 74 & 4 & 296 \\
\hline 3. & Fair & 79 & 3 & 237 \\
\hline 4. & Disagree & 52 & 2 & 104 \\
\hline 5. & Strongly Disagree & 9 & 1 & 9 \\
\hline \multicolumn{4}{|r|}{ Total Likert } & 691 \\
\hline \multicolumn{4}{|c|}{ Max Likert $=223 * 5$} & 1,115 \\
\hline \multicolumn{4}{|c|}{ Likert (in \%)= Total Liker / Max Likert $* 100$} & 61.97 \\
\hline \multicolumn{4}{|r|}{ Statment } & $\begin{array}{l}\text { (between 60- } \\
\text { 79.99) Agree }\end{array}$ \\
\hline
\end{tabular}

The results of the assessment for Service, respondents said Agreed that E-Learning can improve and maintain the learning processes an ensure consistency, completeness and quality of the Mercubuana University's E-Learning.

\section{4) PIECES}

The overall results of the calculations obtained from respondents, it can be seen Efficiency has the highest order using the calculation method Likert score Strongly Agree, while the rest get ratings Agree, namely Economic (79.37\%), Performance (67\%), Information (71.7\%), and Control $(61.61 \%)$. While the Mean value of each point is Performance 3.3677, Information 3.0852, Economic 3.9686, 3.0807 Control, Efficiency 4.0404 and 3.0987 Service. And the overall average is 3.4402 .

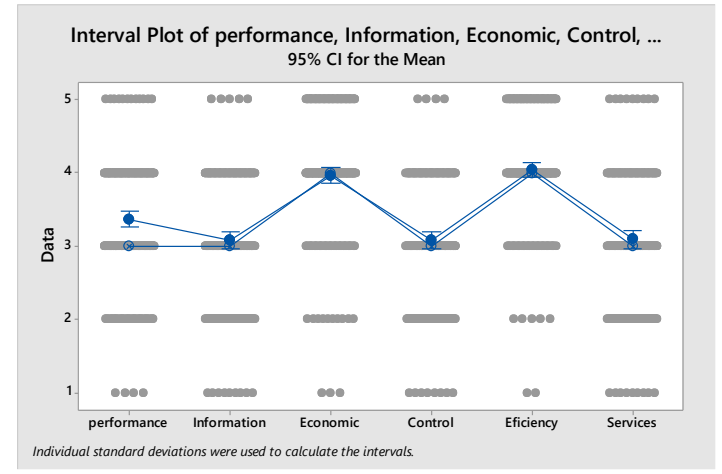

Fig. 8: Interval Plot PIECES

\section{IV.CONCLUSION}

Implementation of e-Learning of the University Mercubuana has value in performance, Information, Economic, Control, and Service. With these results, the University must increase the results on these points in order to have a Strongly Agree value. As for the assessment of the implementation, Efficiency Online Learning is Strongly Agree and must be maintained.

\section{REFERENCES}

[1] Khan. BH. 2005. Managing E-learning: Design, Delivery, Implementation, and Evaluation. George Washington-USA: Infosci.

[2] Jochems, W. et. All. 2004. Integrated E-learning: Implications for Pedagogy, Technology and Organization. New York: USA. RutledgeFlamer.

[3] Davis, J. and Graff, M. 2005. An Evaluation of the Effectiveness of ELearning, Mobile Learning, and Instructor-Led Training in Organizational Training and Development. United Kingdom: British Journal of Educational Technology Vol 36.

[4] Fisher, C. et all. 2011. Introduction to Information Quality. Bloomington-USA: Author House.

[5] Mercubuana. Sejarah Mercubuana. http://mercubuana.ac.id/id/tentangumb/sejarah-umb. [Date acessed, 6th January 2017].

[6] V. Paul, T. An Evaluation of the Effectiveness of E-Learning, Mobile Learning, and Instructor-Led Training in Organizational Training and Development. Taipei-Taiwan: British Journal of Educational Technology Vol 36 No 4.

[7] Kipkurui, N. Evaluating Usability of E-Learning Systems in Universities. Bradford: United Kingdom. IJACSA.

[8] Tullis, W. and Albert W. 2008. Measuring The User ExperienceCollecting, Analyzing, and Presenting Usability Metrics. Burlingron: Elsevier. 